http://dx.doi.org/10.11646/phytotaxa.173.3.3

\title{
Taxonomic studies on the genus Premna (Lamiaceae) in China-I: the identities of $P$. fulva and P. tapintzeana
}

\author{
YUNHONG TAN ${ }^{1} \& \mathrm{BO} \mathrm{LI}^{2 *}$ \\ ${ }^{I}$ Key Laboratory of Tropical Forest Ecology, Xishuangbanna Tropical Botanical Garden, Chinese Academy of Sciences, Mengla, \\ 666303, P. R. China. \\ ${ }^{2}$ Laboratory of Subtropical Biodiversity, Jiangxi Agricultural University, Nanchang, 330045, P. R. China; \\ *Author for Correspondence email: hanbolijx@163.com
}

\begin{abstract}
With 46 species recognized in the Flora of China, Premna is now one of the fifth largest genera in the mint family in China. Current classifications have placed Premna in the family Lamiaceae removing it from the family Verbenaceae, leaving the identity of many of the Chinese species difficult to resolve. In this study, based on protologues, and consulting both herbarium (including the types) and fresh specimens, $P$. crassa is reduced to synonymy of $P$. fulva; $P$. calcicola (ined.), P. crassa var. bijiangensis (ined.), P. crassa var. yuii, P. dopii, P. puerensis, P. shunningensis (ined.), P. straminicaulis, $P$. yuanjiangensis (ined.) and $P$. yunnanensis (nom. illeg.) are recognized as $P$. tapintzeana. Premna fulva and $P$. tapintzeana are similar to each other by having small corymbs, subequal stamens enclosed by the corolla tube, and equal or slightly 2-lipped calyces with 5 obtuse lobes, but also different in the shape of leaf blades and upper corolla lips, the indumentum of branchlets, petioles and peduncles, and their habitat. The present investigation provides complete taxonomic treatments, geographic distributions and ecological observations of $P$. fulva and P. tapintzeana.
\end{abstract}

\section{Introduction}

Premna Linnaeus (1771: 587) has been transferred from the family Verbenaceae to Lamiaceae (Harley et al. 2004, Bramley et al. 2010, Olmstead 2010, 2012). The genus is mainly distributed in Old World tropics and subtropics, and comprises ca. 50 (Mabberley 2008) to 200 species (Verdcourt 1992) in the world. Though some regional revisions of Premna have been done (Munir 1984, Ho 1999, Rajendran \& Daniel 2002, Mabberley \& de Kok 2004, Leeratiwong et al. 2009, de Kok 2013), the complete revision of the genus is missing. So it still ranks among the most taxonomically difficult and complicated genera of Lamiaceae.

Premna is considered one of the fifth largest genera with 46 species in the mint family of the flora of China (Chen \& Gilbert 1994, Li \& Hedge 1994). Among the Chinese species with a lax flat-topped corymb, P. crassa var. yuii Moldenke (1967: 421), P. straminicaulis Wu (1977: 426) and P. tapintzeana Dop (1923: 837) were always morphologically compared with P. crassa Handel-Mazzetti (1921: 230)(P'ei \& Chen 1982, Chen \& Gilbert 1994). However, after examination of type specimens it is found that $P$. crassa (Fig. 1A) is identical to P. fulva Craib (1911: 442)(Fig. 1B) which is distinct from other Premna species by its leaves, which are adaxially reddish brown when dry, and by the covering of dense golden-brown spreading hairs on branchlets, petioles and peduncles. The name "P. crassa" used in China is in conflict with the types of that name, and is instead much more consistent with P. tapintzeana (Fig. 1C), which is characterized by having mostly conical to rarely spherical corymbs, and by the covering of minutely brownish to purplish pubescences throughout. Most of the specimens identified as P. crassa are actually P. tapintzeana. Thus, $P$. crassa is reduced to $P$. fulva as synonym.

Furthermore, Premna crassa var. yuii, P. straminicaulis and P. tapintzeanaare difficult to distinguish clearly. Consulting protologues and herbarium specimens (including the types), and fresh specimens it is determined that $P$. crassa var. yuii (Fig. 1D) and $P$. straminicaulis (Fig. 2A) have no significant differences from $P$. tapintzeana, indicating they are conspecific. In addition, $P$. puerensis Qian (1991: 123; Fig. 2B), is also found to be conspecific with $P$. tapintzeana. Several herbarium specimens bearing invalid names, such as $P$. calcicola $\mathrm{Wu}$ (ined.) (Fig. 2C), P. crassa var. bijiangensis Yang (ined.)(Fig. 2D), P. shunningensis P'ei \& Chen (ined.)(Fig. 2E) and P. yuanjiangensis Yang (ined.)(Fig. 2F) are all also recognized as $P$. tapintzeana. 
Additional specimens examined:-CHINA: Guangxi: Donglan County, Ma'anshan Mountain, 30 June 1939, L.Q. Chen 92171 (IBK sheets no. 00058194, 00058195, 00058197); Jingxi County, Biaolinao, 29 August 1935, X.P. Gao 55672 (IBK sheets no. 00058196, 00058199); Lingle County, near Wuzhishan Mountain, 31 May 1959, Z.T. Li 602998 (PE sheet no. 01276416); Longjing County, Wulian Town, Banbi Village, 1 August 1957, S.Q. Chen 13256 (IBK sheets no. 00058193, 00058201); Napo County, Baidu Town, Nonghua Village, 16 September 1983, D. Fang et al. 25246 (GXMI sheet no. 029831); Pingguo County, Chaiguang Town, 2 June 1957, Y.K. Li P01349 (IBK sheets no. 00058198, 00058195); Tiandong County, Xiangzhou Town, 22 June 1977, Q. Mu 3-1430 (GXMI sheet no. 042884); Guizhou: An'Shun County, Shuangjiang Town, balai, 12 July 1959, An 'Shun Exp. 292 (KUN sheet no. 198439); Cehen County, north of the city, 16 September 1958, Z.Y. Cao 717 (KUN sheet no. 198438); No location data, 22 September 1936, S.W.Deng 91015 (MO sheet no. 04175476); Yunnan: Binchuan County, Waxi to Dayinjie, 15 October 1945, S.Liu 21613 (PE sheet no. 01276417); Fengqing County, Hila, 22 June 1938, T.T. Yu 16415 (KUN sheet no. 198436, PE sheets no. 00029785, 00029786); Funing County, Chia-chieh, 21 May 1940, C.W. Wang 89449 (PE sheet no. 01276419); Funing County, Guichao Town, Jiagai, 17 May 1940, C.W. Wang 89308 (HITBC sheet no. 046663, KUN sheets no. 198428, 198429, 198432, 198433); Jinping County, Menglaba, Huiyang, 20 April 1956, Sino-Russia Exp. 129 (KUN sheet no. 198425); Mengla County, Mengyuan Town, in limestone slopes, May 1982, Yunnan Exp. 32618 (HITBC sheet no. 046486); Tengchong County, Xinhua Town, near Longjiang River, 24 April 1980, anonymous s.n. (HITBC sheet no. 080680); Wenshan County, Shii-guu, in mixed forests, 21 August 1947, G.M. Fen 11398 (KUN sheet no. 198434); Xichou County, Yongxin Town, 16 July 1958, Y.Y. Hu 580707 (KUN sheet no. 198437); Yanshan County, Ti-mi-ho-shan, 3 October 1939, C.W. Wang 84176 (KUN sheets no. 198427, 198430, 198431).

\section{Acknowledgements}

The authors are grateful to the keepers of BM, HITBC, KUN, P, PE, W for providing and allowing reproduction of the images of herbarium specimens, to Dr. Zhonghui Ma and Mr. Zhuqiu Song for field assistances and to Dr. Uromi Manage Goodale for assistance with the manuscript preparation.

\section{References}

Blanco, M. (1837) Flora de Filipinas, según el sistema de Linneo. Inprenta de Sto. Thomas por D. Candido Lopez, Manila, 887 pp. http://dx.doi.org/10.5962/bhl.title.48447

Bramley, G.L., Forest, F. \& de Kok, R.P.J. (2010) Troublesome tropical mints: re-examining generic limits of Vitex and relations (Lamiaceae) in South East Asia. Taxon 58: 500-510.

Chen, S.L \& Gilbert, M.G. (1994) Premna. In: Wu, C.Y. \& Raven, P.H. (eds.) Flora of China, Vol. 17. Science Press, Beijing \& Missouri Botanical Garden Press, St. Louis, pp. 16-27.

Craib, W.G. (1911) Contributions to the Flora of Siam: list of Siamese plants with descriptions of new species (continued). Bulletin of Miscellaneous Information Kew 10: 442-443.

http://dx.doi.org/10.2307/4115077

Dop, P. (1923) Contribution à l'étude du genre Premna L. Bulletin de la Société Botanique de France 70: 836.

Handel-Mazzetti, H.R.E. (1921) Abhandlungneueaufnahmen in NW-Junnan und S-Setschuan nr. 19. Anzeiger der Akademie der Wissenschaften in Wien, Mathematisch-Naturwissenschaftliche Klasse 58: 210-271.

Harley, R.M., Atkins, S., Budantsey, A.L., Cantino, P.D., Conn, B.J., Grayer, R., Harley, M.M., de Kok, R., Krestovskaja, T., Morales, R., Paton, A.J., Ryding, O. \& Upson, T. (2004) Labiatae. In: Kubitzki, K. \& Kadereit, J.W. (eds.) Families and genera of vascular plants. Flowering plants. Dicotyledons - Lamiales (except Acanthaceae including Avicenniaceae), Vol. 7. Springer, Berlin, pp. $167-275$. http://dx.doi.org/10.1007/978-3-642-18617-2_11

Ho, P.H. (1999) Cay Co Viet Nam: an illustrated flora of Viet Nam, Vol. 2. NhaXuat Ban Tre, TP. Ho Chi Minh, 953 pp.

deKok, R.P.J. (2013) The genus Premna L. (Lamiaceae) in the Flora Malesiana area. Kew Bulletin 68: 55-84. http://dx.doi.org/10.1007/s12225-013-9433-5

Leeratiwong, C., Chantaranothai, P. \& Paton, A (2009) A synopsis of the genus Premna L. (Lamiaceae) in Thailand. The Natural History Journal of Chulalongkorn University 9: 113-142.

Linnaeus, C. (1771) Mantissa plantarum. Salvius, Stockholm, 587 pp.

Li, H.W. \& Hedge, I.C. (1994) Lamiaceae. In: Wu, C.Y. \& Raven, P.H. (eds.) Flora of China, Vol. 17. Science Press, Beijing \& Missouri 
Botanical Garden Press, St. Louis, pp. 269-291.

Mabberley, D.J. (2008) Mabberley's plant-book: a portable dictionary of plants, their classifications, and uses, 3rd edition. Cambridge University Press, Cambridge, 1040 pp.

Mabberley, D.J. \& de Kok, R.P.J. (2004) Labiatae. In: Morat, P. \& Mackee, H.S. (eds.), Flore de la Nouvelle-Calédonieet Dépendances, Vol. 25. Muséum National D’Histoire Naturelle, Paris, pp. 20-141.

Merrill, E.D. (1906) New or noteworthy Philippine plants V. Philippine Journal of Science 1: 169-246. http://dx.doi.org/10.5962/bhl.title.11045

Moldenke, H.M. (1967) Three new subspecific taxa in Petrea, Premna and Vitex. Phytologia 18: 421.

Munir, A.A. (1984) A taxonomic revision of the genus Premna L. (Verbenaceae) in Australia. Journal of the Adelaide Botanic Gardens 7: $1-44$.

Newman, M., Ketphanh, S.,Svengsuksa, B., Thomas, P., Sengdala, K., Lamxay, V. \& Armstrong, K. (2007) A Checklist of the vascular plants of Lao PDR. Royal Botanic Gardens Edinburgh, Edinburgh, 394 pp.

Olmstead, R.G. (2010) A Synoptical Classification of the Lamiales. Version 2.2. https://my-plant.org/sites/default/files.

Olmstead, R.G. (2012) A Synoptical Classification of the Lamiales. Version 2.4. http://depts.washington.edu/phylo/Classification.pdf.

P'ei, C. (1932) The Verbenaceae of China. Memoirs of the Science society of China 1: 58-91.

P'ei, C. \& Chen, S.L. (1982) Premna. In: Pei, C. \& Chen, S.L. (eds.) Flora Reipublicae Popularis Sinicae, Vol. 65. Science Press, Beijing, pp. 81-119.

Qian, Y.Y. (1991) Three new species from Yunnan. Guihaia 11: 121-126.

Rajendran, A. \& Daniel, P. (2002) The Indian Verbenaceae. Shiva Press, Dehra Dun, 431 pp.

Smith, W.W. (1916) Diagnoses specierumnovarum in herbario Horti Regii Botanici Edinburgensis cognitarum (Species chinenses.) CLLCCL. Notes from the Royal Botanic Garden, Edinburgh 9: 120-121.

Verdcourt, B. (1992) Verbenaceae. In: Polhill, R.M. (ed.) Flora of tropical east Africa. Balkema, Rotterdam, pp. 1-156.

Wu, C.Y. (1977) Premna. In: Kunming Institute of Botany, Academia Sinica (eds.) Flora Yunnanica, Vol. 1. Science Press, Beijing, pp. $418-441$ 